\title{
Experimental study of cross-laminated timber wall panels
}

\author{
Johan Vessby • Bertil Enquist · Hans Petersson · Tomas Alsmarker
}

Received: 4 July 2008 / Published online: 19 February 2009

(C) Springer-Verlag 2009

\begin{abstract}
The use of cross-laminated structural timber elements is becoming increasingly popular. The number of layers varies normally from three upwards. The structural performance of five-layer cross-laminated timber elements was investigated. The five layers consisted of $19 \mathrm{~mm}$ thick boards, laid successively at right angles to each other and glued together with PU-adhesive, layers 1, 3 and 5 lying in one direction and layers 2 and 4 in the other. The stiffness and strength of four cross-laminated timber elements $(4955 \mathrm{~mm}$ long, $1250 \mathrm{~mm}$ wide and $96 \mathrm{~mm}$ thick) were studied during in-plane bending. Two of the elements were first partitioned into two parts that were reconnected in two different ways prior to testing. The influence of the way in which the crosslaminated timber elements were reconnected was studied, the behaviour observed being compared with the test results for the unpartitioned specimens with respect to both strength and stiffness. The experimental tests performed showed the cross-laminated timber elements to possess a high degree of stiffness and strength. There was also found to be a marked difference in behaviour between the two different ways in which the elements were connected to each other. One of the two connecting methods studied, being of less good design but earlier frequently used in Sweden, showed as expected poor structural performance, whereas the other one applied as a safer alternative performed well.
\end{abstract}

J. Vessby $(\square) \cdot$ B. Enquist $\cdot$ H. Petersson

Department of Design and Technology, Växjö University,

Lückligs plats 1 ,

35195 Växjö, Sweden

e-mail: johan.vessby@vxu.se

T. Alsmarker

Tyrens AB,

Peter Myndes Backe 16,

11886 Stockholm, Sweden

\section{Experimentelle Untersuchung von Wandelementen aus Brettsperrholz}

Zusammenfassung Die Verwendung von Brettsperrholzbauteilen aus drei oder mehr Lagen gewinnt zunehmend an Beliebtheit. Das Trag- und Verformungsverhalten von fünflagigen Brettsperrholzelementen wurde untersucht. Die fünf Lagen bestanden aus $19 \mathrm{~mm}$ dicken, kreuzweise mit PU-Klebstoff verklebten Platten, wobei Lagen 1, 3 und 5 in eine Richtung und Lagen 2 und 4 in die andere Richtung orientiert waren. Die Biegesteifigkeit und -festigkeit in Plattenebene von vier Brettsperrholzelementen (4955 mm lang, $1250 \mathrm{~mm}$ breit und $96 \mathrm{~mm}$ dick) wurden untersucht. Zwei der Elemente wurden in Längsrichtung mittig aufgetrennt und dann vor der Prüfung auf zwei verschiedene Arten wieder miteinander verbunden. Untersucht wurde der Einfluss der Art der Verbindung der Brettsperrholzelemente auf die Festigkeit und Steifigkeit der Elemente durch Vergleich mit den Versuchsergebnissen der nicht geteilten Prüfkörper. Die Versuche ergaben, dass die Brettsperrholzelemente eine hohe Steifigkeit und Festigkeit aufwiesen. Es zeigte sich ein deutlicher Unterschied im Verhalten der zwei Arten der Wiederverbindung der beiden Elemente. Erwartungsgemäß ergab die weniger gute aber früher in Schweden oft verwendete Verbindungsart schlechte Ergebnisse, wohingegen die andere Verbindung, eine sicherere Alternative, gute Ergebnisse lieferte.

\section{Introduction}

Multi-storey timber-based structures have long been built in many different countries. Various challenges are connected with constructions of this type. One such challenge 
is that of stabilising the structure against horizontal wind loads. The most common stabilising system involves the use of a sheathing material such as OSB, plywood or gypsum, connected to the timber frame by nails or screws. Shear forces are thus transmitted by the connectors from the timber frame to the sheathing. The wall elements between separate stories are often connected by means of special brackets or some other form of hold-down devices. The design principles involved and the calculation methods employed have been dealt with extensively in the literature Källsner and Lam (1995), Kasal et al. (2004) and Ellis and Bougard (2001). In many cases, a stiffer wind bracing system of greater strength may be of interest, particularly in the case of narrow houses that are tall but have a relatively small foundation area. For houses in which the walls are perforated by door and window openings special structural design measures are often needed. In such buildings, the use of cross-laminated timber elements, either as parts of the walls or in the walls as a whole, can be of strong interest, a matter which has been studied for example by Dujic et al. (2004), Blass and Fellmoser (2004) and Moosbrugger et al. (2006). In heavily loaded parts of the walls, the connections between the cross-laminated wall panels are highly important for structural performance. The aim of the present study was to gain greater insight into the behaviour of structures of this type by investigating cross-laminated timber elements experimentally. Both the stiffness and strength of the elements and the ways of connecting the wall elements with each other were studied.

\section{Tested specimens}

Four wall elements of cross-laminated timber $4955 \mathrm{~mm}$ in length, $1250 \mathrm{~mm}$ in width and $96 \mathrm{~mm}$ thick were tested. The elements consisted of five layers of sawn boards, the successive layers being glued crosswise to each other. The fibres of the two outermost layers, 1 and 5, and of the middle layer, 3 , extended in the direction of the length of the element, whereas layers 2 and 4 extended in the direction perpendicular to this, see Fig. 1. The $19 \mathrm{~mm}$ thick sawn boards of which these timber elements were composed were made of Norway spruce and were on the average about $120 \mathrm{~mm}$ in width. In the long direction, the boards were placed butt to butt with a random location of the butt joints, there being no finger joints connecting them. The boards were not strength graded but expected to be of class $\mathrm{C} 24$ or higher grade. The equilibrium moisture content of these elements was found to be about $13 \%$ at the time of testing. The highest and the lowest moisturecontent values in a given board differed by about $2 \%$. It is assumed that in the elements tested the variations in the material properties due to differences in moisture content were negligible.

\section{Testing of joints}

After stiffness testing of the elements 1 and 2 at a low load level, these two cross-laminated timber elements were sawn into two parts. These parts were then reconnected by use
Fig. 1 The five-layer cross-laminated timber-wall elements tested Abb. 1 Untersuchte Wandelemente aus fünflagigem Brettsperrholz
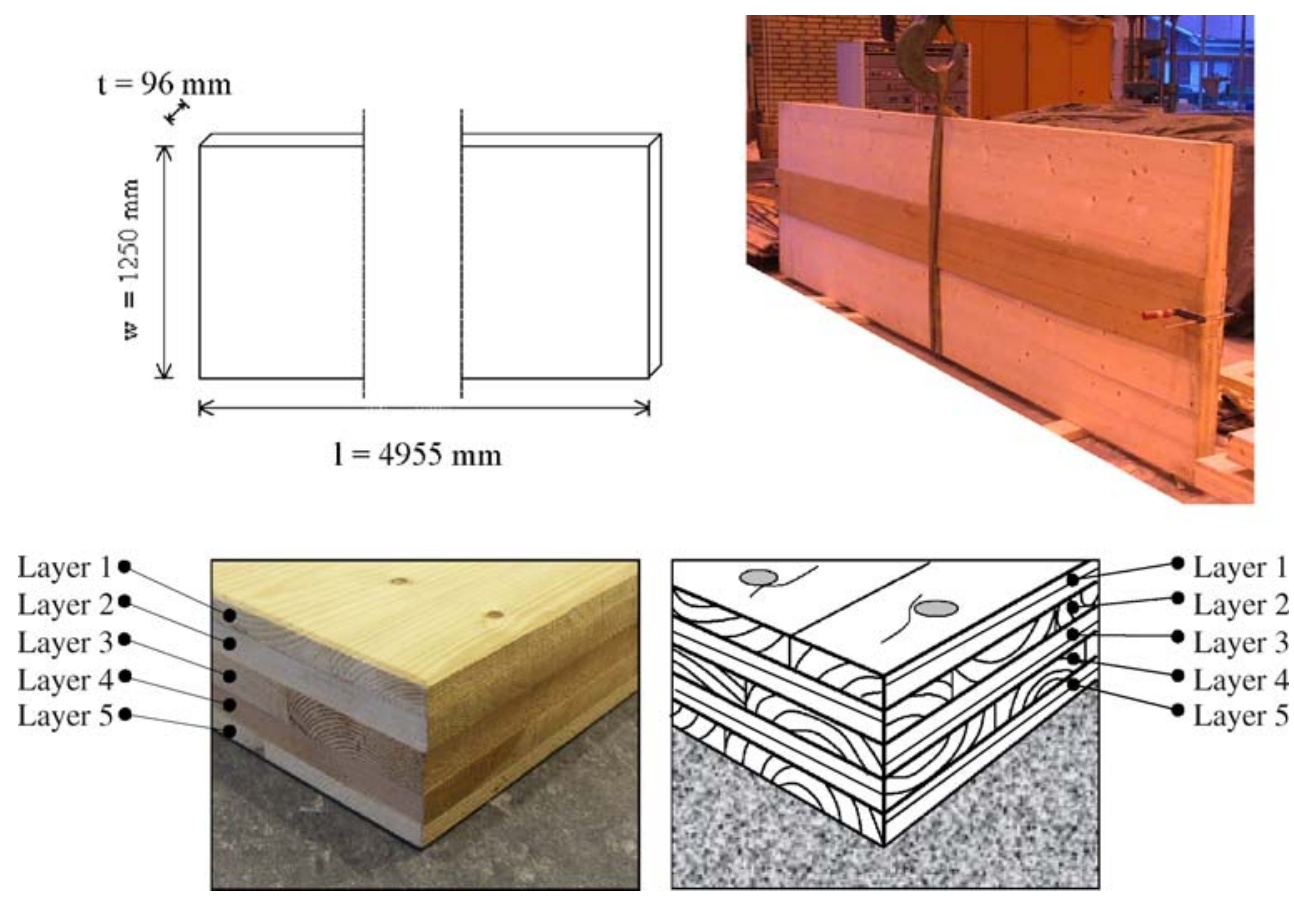
of two different jointing methods. The new wall elements having longitudinal joints were renamed as element 5 (made from element 1 ) and element 6 (made from element 2 ).

For element 5, a purely mechanical joint was employed. After this element had been partitioned, a $60 \mathrm{~mm}$ deep and $25 \mathrm{~mm}$ wide slot was cut into each of the two halves. A sawn board $120 \mathrm{~mm}$ wide, $25 \mathrm{~mm}$ thick and graded as C24 was fitted into the slot. Hexagonal-head wood screws, $96 \mathrm{~mm}$ long and $8 \mathrm{~mm}$ in diameter, were screwed both from the left and the right into the two sides of the element. This poor design, with the solid board and the hexagonal-head screws, of the joint was used in the experiment since similar joints have earlier been much used in practical design, although their capacity has never been verified experimentally. The screws were mounted in a row both from the first and the second side in predrilled holes as shown in Fig. 2a. By placing them in a single row like this the worst case was obtained from a shear force perspective.

For element 6 both gluing and screwing were used for the joint. A sheet of fibreboard of quality $\mathrm{C} 40$ (wet process fibreboard, HB.HLA2, Masonite AB) $300 \mathrm{~mm}$ wide and $8 \mathrm{~mm}$ thick was applied to both sides of the partitioned specimen, see Fig. 2b. The adhesive used was a single-component polyurethane with a curing time of approximately $12 \mathrm{~h}$. In addition the sheets of fibreboard were also fastened mechanically by means of $50 \mathrm{~mm}$ long hexagonal-head wood screws $6 \mathrm{~mm}$ in diameter located in two parallel rows, as shown in Fig. 2b. The distributed normal forces from the screws resulted in a proper gluing pressure.

\section{Tests of stiffness and strength}

An overview of the tests performed for the wall elements numbered 1 to 6 are given in Table 1. A schematic diagram of the testing setup is presented in Fig. 3. The loading in the vertical plane of a simply supported cross-laminated timber element, acting as a horizontal beam, is similar to the loading of a cantilever wall element of half the length fixed to the ground.

The elements 1 to 4 were first loaded in a non-destructive way at a low loading level in order to determine their initial stiffness. Each of the elements was loaded by the testing machine, see Fig. 4, under displacement control to a load of $200 \mathrm{kN}$ and was then unloaded. The crosshead a

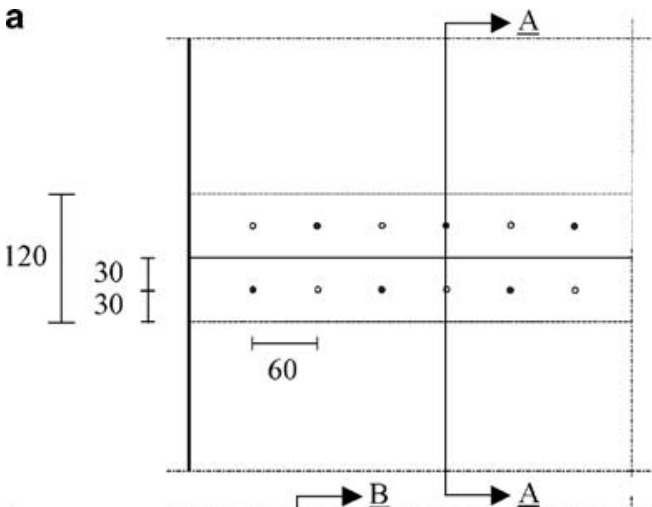

b

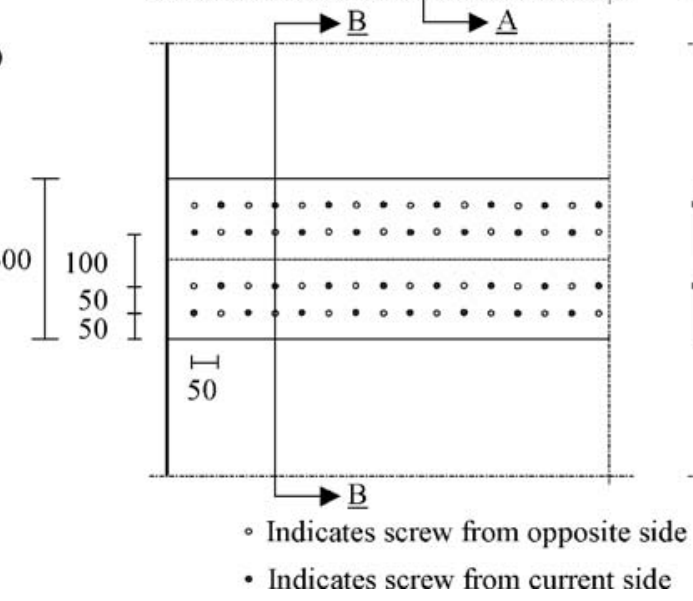

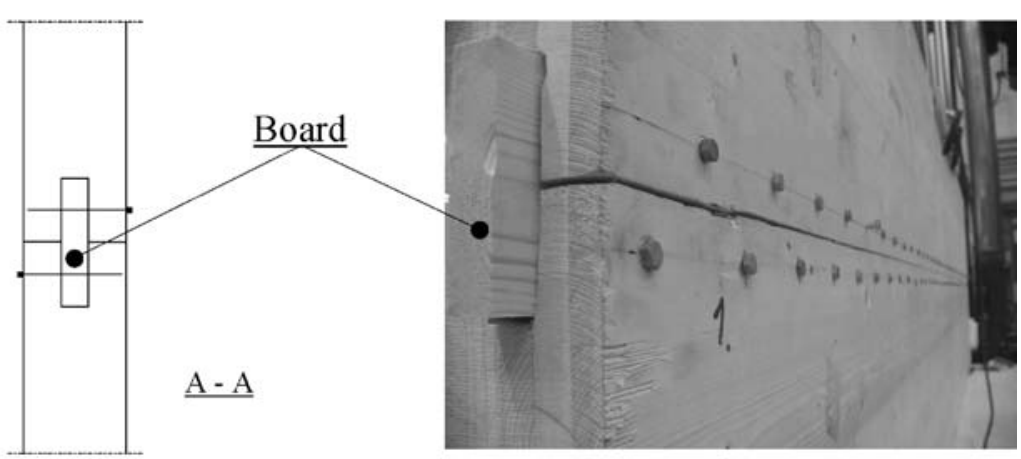

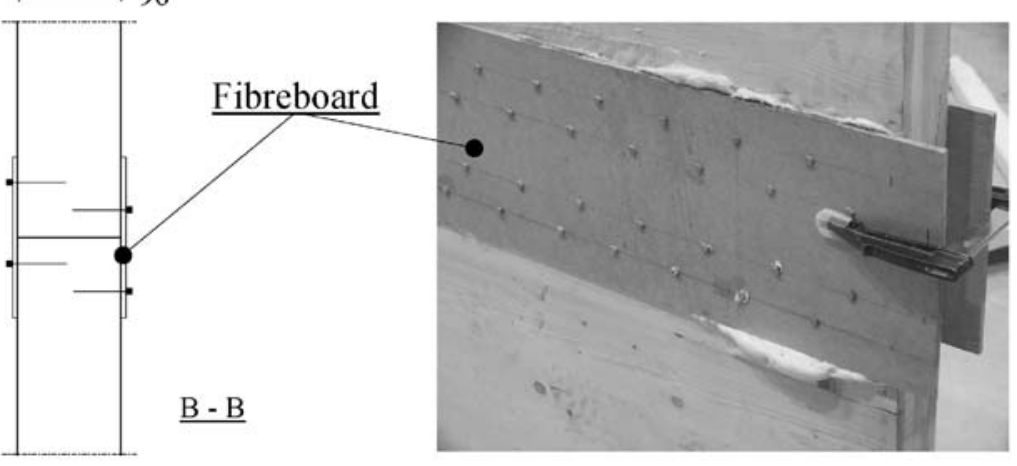

Fig. 2 Joints of the longitudinal wall-elements: (a) element 5 with a sawn board screwed to the parts of the element and (b) element 6 with fiberboard sheets glued and screwed to the parts of the element

Abb. 2 Längsverbindung der Wandelemente (a) Element 5, bei dem die Teile mit einem Brett verschraubt wurden und (b) Element 6, bei dem Faserplatten beidseitig mittels Schraubpressklebung aufgeklebt wurden 
Fig. 3 (a) Schematic plan of the testing setup, (b) photograph of the testing machine. (The dotted line indicates a longitudinal joint such as for elements 5 and 6) Abb. 3 (a) Schema des Versuchsaufbaus (die gestrichelte Linie zeigt eine Trennfuge wie bei den Elementen 5 und 6) (b) Foto der Prüfmaschine a

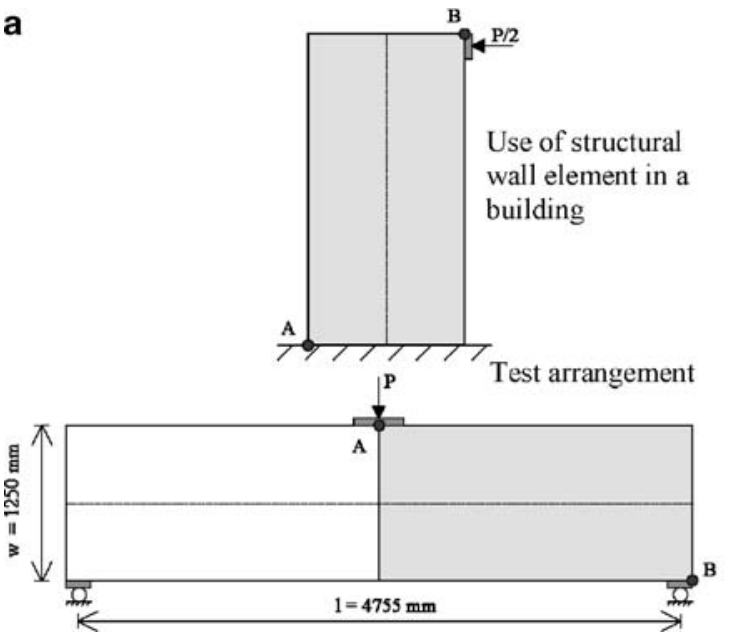

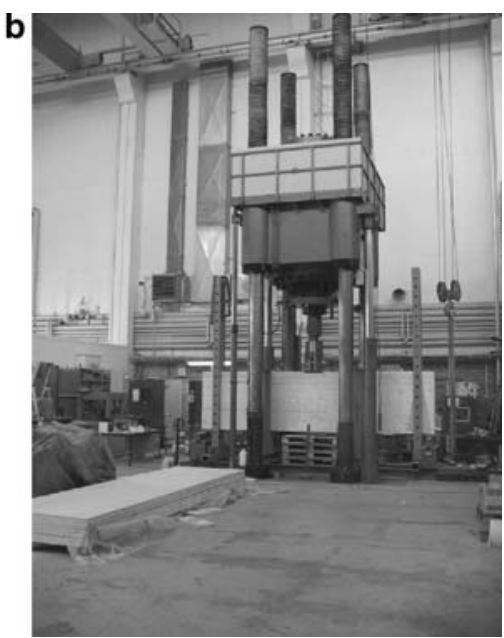

Table 1 Course of events for the elements tested

Tabelle 1 Versuchsablauf der untersuchten Elemente

\begin{tabular}{ll}
\hline Element & Course of events \\
\hline 1 & Stiffness only tested in the load interval 0-200 kN \\
3 & Stiffness only tested in the load interval 0-200 kN \\
4 & Stiffness test. Loading to failure \\
5 & Stiffness test. Loading to failure \\
& Made by cutting element 1 into two halves and then reconnecting the two halves by use of a sawn board screwed \\
6 & to the parts of the element. Loading to failure \\
& Made by cutting element 2 into two halves and then reconnecting the two halves by screwing and gluing of fibreboard sheets \\
& to the parts of the element. Loading to failure
\end{tabular}

movement of the hydraulic jack proceeded at a rate of $2 \mathrm{~mm} / \mathrm{min}$.

The hydraulic testing machine had a capacity of $20 \mathrm{MN}$ and the accuracy in force measurement was about $\pm 2.3 \mathrm{kN}$ for the maximum load used in this test.

In the stiffness tests the displacements were measured by use of gauges, as shown in Fig. 4. Gauges 1 and 3 were placed at half-height above the centre of the support on the left and right side, respectively, there measuring the vertical deflection above the supports, relative to the supports. Displacement gauges 2 and 4, in turn, measured the vertical deflection at half-height and mid-span on each side of the element. Gauge 5 measured the mid-deflection at halflength on the underside of the element. The displacement gauges 6 and 7 were added in testing elements 5 and 6 . These two gauges were used to measure the relative slip at the ends of the longitudinal joint connecting the two parts of the elements studied.

The supports provided at the two ends held the element for vertical translation, the element being free to move horizontally at both supports. These two solid steel supports were $200 \mathrm{~mm}$ long and $50 \mathrm{~mm}$ thick, whereas the steel plate at the loading point was $400 \mathrm{~mm}$ long. Horizontal translation of the elements was prevented by friction at the loading point. Translation out of the plane of the elements tested was prevented by supporting surfaces of low friction. These surfaces were placed in couples on both sides of the element (at $x=350 \mathrm{~mm}, x=1450 \mathrm{~mm}, x=3500 \mathrm{~mm}$ and $x=4600 \mathrm{~mm}, x$ being the distance from the left support). The testing setup is shown schematically in Fig. 4, together with photos of a displacement gauge and the support arrangement.

\section{Results}

\subsection{Stiffness}

Considering the specimens tested as constituting deep beams, the deformations observed can be seen as representing contributions of three major types, those from bending, shear and local material compression, at the loading and supporting areas. Due to the orthogonal orientation of the different layers in the timber elements, the material compression could be kept relatively small. Both at the support and at the loading point, the timber was loaded parallel to the grain in two of the five layers.

The mid-deflections measured in the six specimens tested were used for determining the overall bending and shear stiffness. In Fig. 5 the mid-displacement curves obtained for 
Fig. 4 Setup for measuring the displacement

Abb. 4 Vorrichtung zur Verformungsmessung

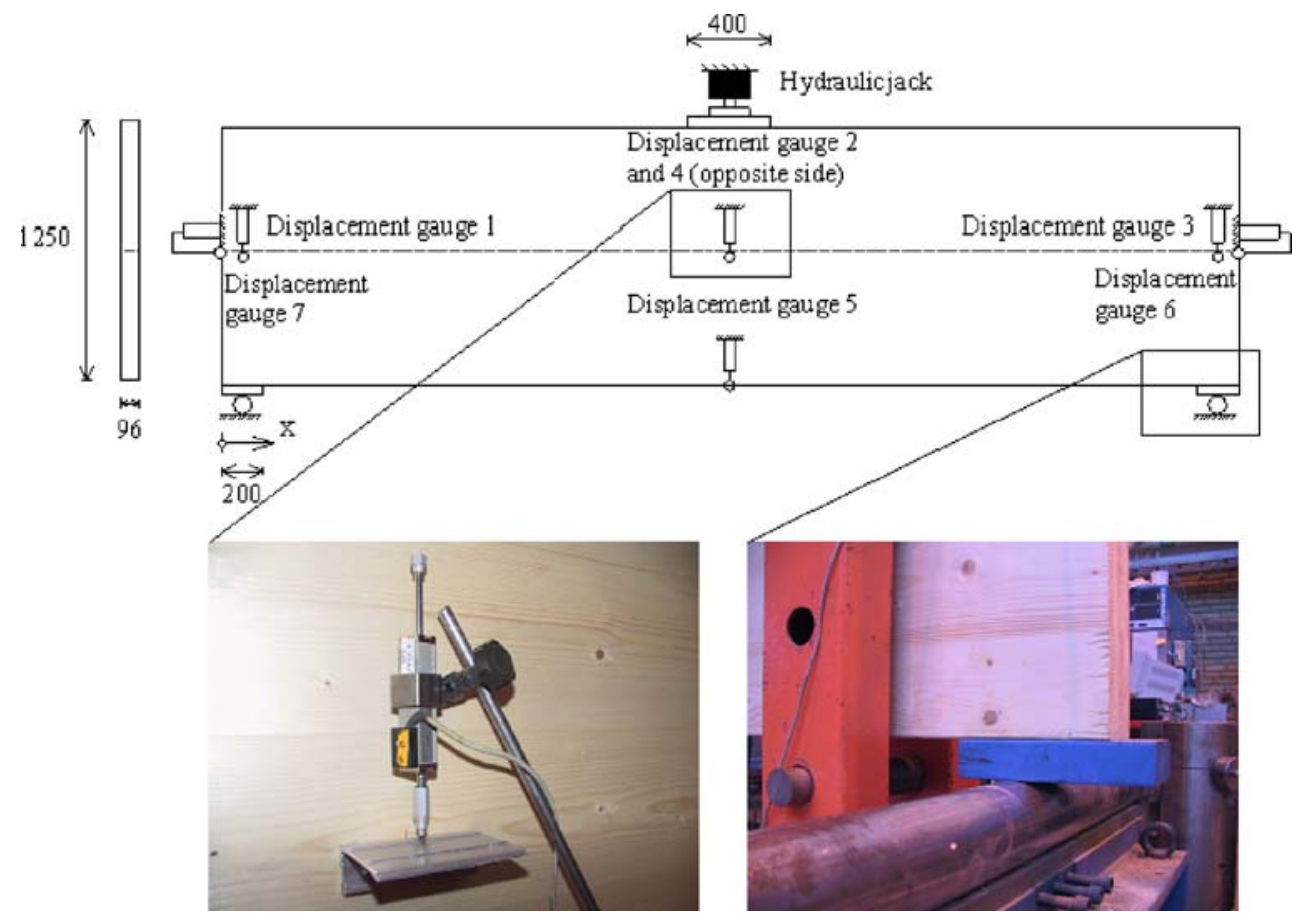

elements 1 to 6 are shown. The values presented were determined by subtracting the respective averages of the values obtained at gauges 1 and 3 from the corresponding averages obtained at gauges 2 and 4, see Fig. 4. The behaviour for each of the six elements is nearly linear. For a load of $100 \mathrm{kN}$ the mid-displacement was about $3 \mathrm{~mm}$ for each of the elements except for element 5 , where the displacement was much larger.

The displacements measured by gauges 1 and 3, see Fig. 4, provide a measure of the local deformations above the supports. Some of the results for the low load values, obtained for element 2, are shown in Fig. 6 illustrating a behaviour that was typical. Due to a non-perfect fit between

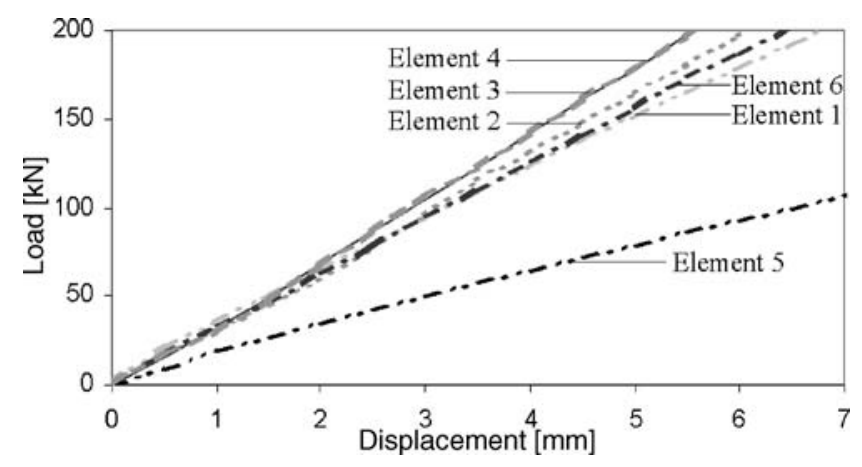

Fig. 5 Load-displacement relations for elements 1 to 6 , used for determining the total stiffness in regard to the bending and shear modes Abb. 5 Kraft-Weg-Diagramme der Elemente 1 bis 6, die zur Bestimmung der Gesamtsteifigkeit (Biegung und Schub) benutzt wurden

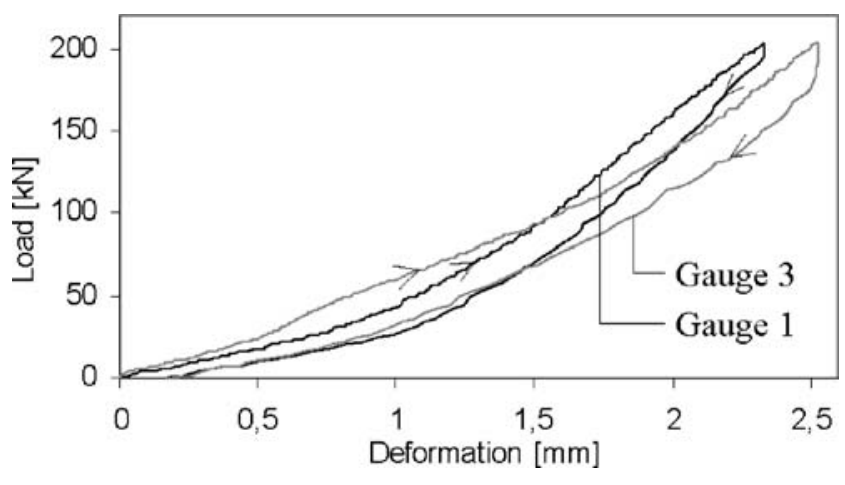

Fig. 6 Measured deformation of element 2 above the supports for a low load level

Abb. 6 Verformung von Element 2 an den Auflagern bei geringer Belastung

the specimen and the supporting steel plates the response is nonlinear at first. From a load of about $30 \mathrm{kN}$ and upwards, the behaviour then becomes almost linear. After unloading, the displacement that remained due to local deformations was less than $0.2 \mathrm{~mm}$.

\subsection{Loading to failure}

After loading the specimens up to $200 \mathrm{kN}$ and reloading, they were loaded to failure. The displacement at the loading point was gradually increased, the magnitude of the load being recorded. The load-displacement curves for elements 3 to 6 are shown in Fig. 7. Up to failure, 


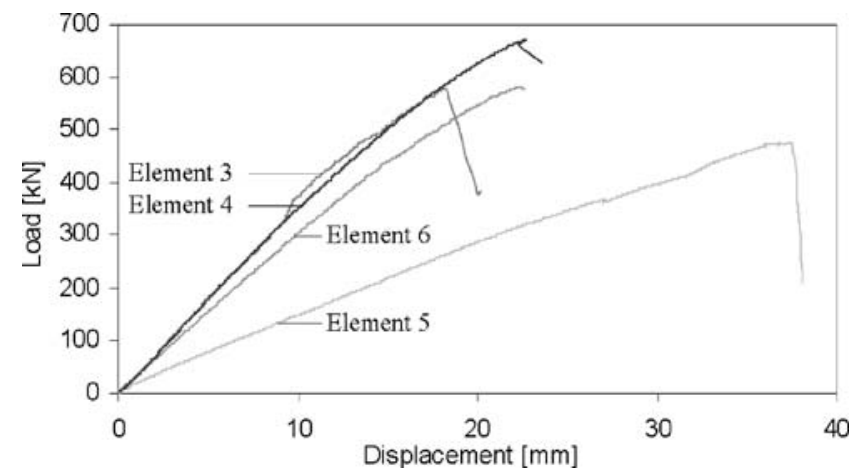

Fig. 7 Load displacement curves for elements 3 to 6 while being loaded to failure

Abb. 7 Kraft-Weg-Diagramme der Elemente 3 bis 6 bei Belastung bis zum Bruch

which occurred suddenly, each of the elements behaved almost linearly. Element 5, with its simple mechanical fasteners in the longitudinal joint, was much weaker than elements 3, 4 and 6. This indicates a considerable difference in behaviour between the two alternative ways of connections used at the joints. In contrast, the difference in behaviour between element 6 , which had glued and screwed fiberboard sheets in the joint, and elements 3 and 4 without any joints, is small. It is notable how very small the difference is between the load-deformation curves for elements 3 and 4, except for the difference in failure load.

It was characteristic for all four specimens that failure occurred suddenly. Once the failure load had been reached, the entire load-bearing capacity disappeared at once, there being no ductile behaviour. Two main types of failure occurred: bending failure and local failure at the support and loading point, respectively. Elements 3 and 5 both failed in bending due to the high tensile forces the boards were subjected to, whereas elements 4 and 6 failed at the loading point and at the support, respectively. The course of event for the latter two elements was similar. At the failure load a sudden loud noise was heard when rupture of the wooden material at the support or at loading point occurred. Each of the failure modes can be seen in Fig. 8.

Table 2 provides an overview of the experimental results obtained. The stiffness defined as the ratio between the point load applied and the measured mid-deflection are based on the load interval $0-200 \mathrm{kN}$. For the reused element 1 and 2 only stiffness values can be presented and were found to be 29.7 and $33.0 \mathrm{MN} / \mathrm{m}$, respectively. The highest failure load reached for element 4 was about $40 \%$ higher than for element 5 , which likewise had an inferior joint design. Note that element 6 , jointed by use of glued fibreboard, had a somewhat higher failure load than element 3 without any joint. This indicates clearly that the joint design used for element 6 worked well from a structural point of view.

In Table 2 the calculated stress values are presented corresponding to the failure loads of the specimens. The average support stress at the supports and at the loading points was calculated by assuming the stresses to be concentrated at the two layers of the cross-laminated elements where the grain direction is oriented perpendicular to the supporting plane. Also, the so-called effective tensile stress due to bending was calculated in an approximate way by considering only the three layers where the grain direction was parallel to the length of the specimens.

For an adequate serviceability state analysis of a reasonably accurate estimate of the stiffness is needed. To achieve this, the experimental results for the combined bending and shear stiffness were compared with the results of simple hand calculations based on ordinary material data and simple beam theory, including shear. The influence of each of the five layers of the cross-laminated specimens was taken into account.

The longitudinal modulus of elasticity was set to $E_{1}=$ $12000 \mathrm{MPa}$ and the transversal modulus of elasticity to $E_{\mathrm{t}}=400 \mathrm{MPa}$, corresponding to an effective longitudinal modulus of elasticity of $E_{\text {eff }}=7360 \mathrm{MPa}$ for the five layers. The shear modulus $G_{\text {eff }}$ was assumed to be $750 \mathrm{MPa}$. On the basis of these assumptions, of the formula used, and of a loading of $200 \mathrm{kN}$, the mid-deflection becomes $7.1 \mathrm{~mm}$, $55 \%$ of which is due to bending, the rest being due to shear. In the experimental test, the average displacement was $6.1 \mathrm{~mm}$, indicating the value of the longitudinal E-modulus of the specimens tested to be somewhat higher than the assumed value of $12000 \mathrm{MPa}$.

The relative slip at the ends of the joints in elements 5 and 6 was measured. The displacement gauges 6 and 7 were placed horizontally on each side of the two partitioned

Table 2 Stiffness, failure load and stress values at failure for the specimens tested

Tabelle 2 Steifigkeit, Bruchlast und Bruchspannung der untersuchten Prüfkörper

\begin{tabular}{llllll}
\hline $\begin{array}{l}\text { Element } \\
\text { number }\end{array}$ & $\begin{array}{l}\text { Stiffness } \\
{[\mathrm{MN} / \mathrm{m}]}\end{array}$ & $\begin{array}{l}\text { Failure } \\
\text { load }[\mathrm{kN}]\end{array}$ & $\begin{array}{l}\text { "Effective" bending } \\
\text { stress }[\mathrm{MPa}]\end{array}$ & $\begin{array}{l}\text { Average support } \\
\text { stress [MPa] }\end{array}$ & $\begin{array}{l}\text { Failure } \\
\text { modes }\end{array}$ \\
\hline 3 & 35.7 & 577 & 48.0 & 37.6 & Tensile failure in bending \\
4 & 35.8 & 672 & 55.9 & 43.8 & Local compression failure at the support \\
5 & 14.6 & 475 & 39.5 & 30.9 & Joint failure. Tensile failure in bending \\
6 & 30.8 & 580 & 48.3 & 37.8 & Local compression failure at the loading point \\
\hline
\end{tabular}




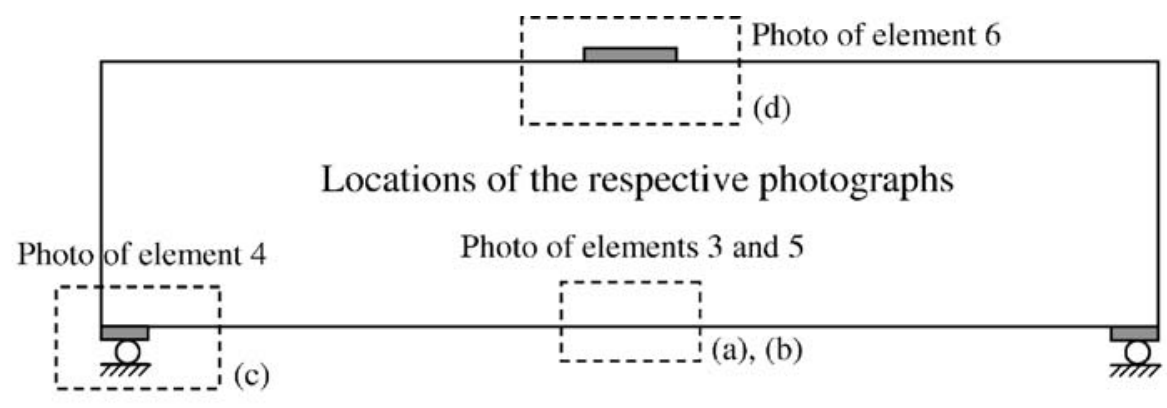

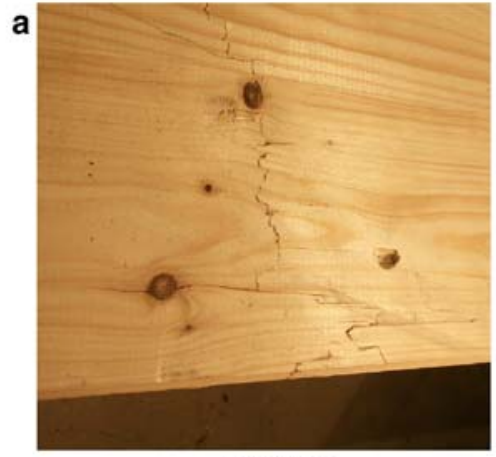

Element 3

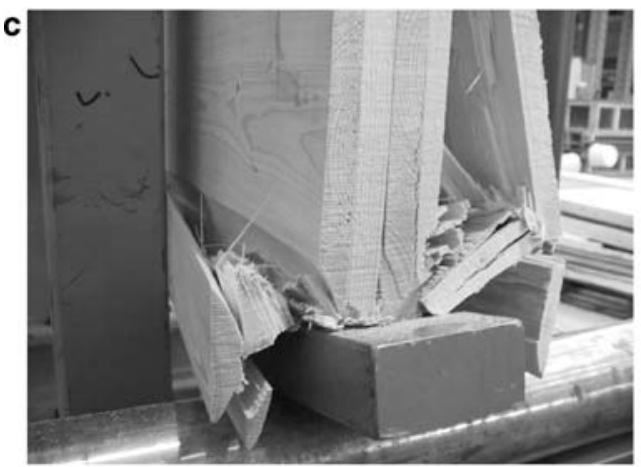

Element 4

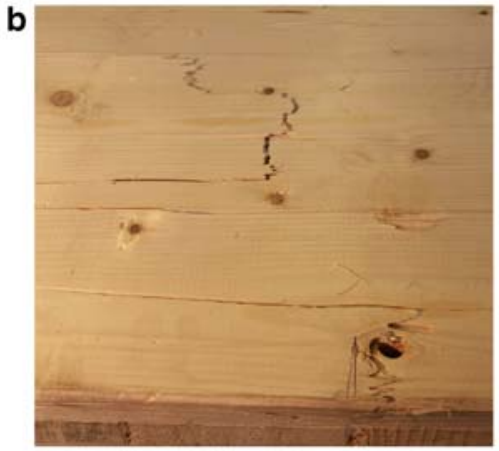

Element 5

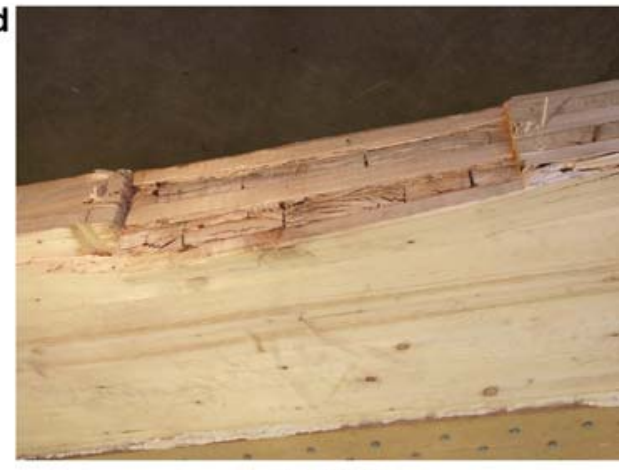

Element 6

Fig. 8 Failure modes and location of each for the four elements, bending failure being involved for elements 3 and 5, and failure at the support and failure close to the load application point for element 4 and element 6 , respectively

Abb. 8 Bruchbilder und Bruchstellen der vier Elemente 3 bis 6; Elemente 3 und 5: Biegebruch Element 4: Bruch am Auflager, Element 6: Bruch im Lasteinleitungsbereich

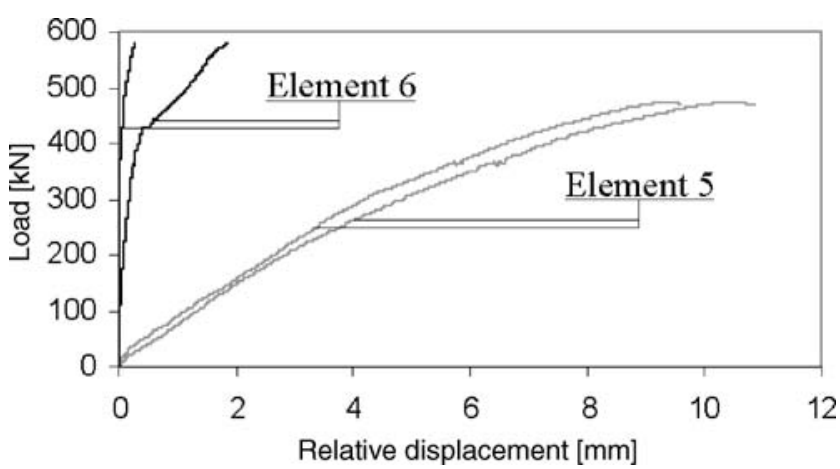

Fig. 9 The slips measured in the joints of elements 5 and 6, the measurements being made at both ends of the respective longitudinal joint Abb. 9 Verschiebung in den Elementen 5 und 6 (an beiden Enden der jeweiligen Verbindung gemessen) elements 5 and 6, respectively, see Fig. 4. The relative slip horizontally measured (as absolute values) between the two halves, can be seen in Fig. 9. The slip for element 5 was much greater than in the case of the glued and screwed connections used for element 6 showing further the very low degree of stiffness of element 5 , which resulted in a much larger deformation of the specimen than for the other specimens tested, as can be seen in Fig. 7.

\section{Conclusion}

Testing a number of cross-laminated timber element specimens experimentally with respect to their stiffness and 
strength provided useful results. Two of the specimens were partitioned into two parts and were then reconnected, two alternative joining methods being employed. It was shown that for one of the two jointing alternatives the connection between the joined parts was just as strong and stiff as for the corresponding elements without a joint. The weaker alternative of using only mechanical connectors and a sawn board as a connecting medium is not to be recommended since the resulting strength and the stiffness were much too low.

The high level of stiffness obtained for the crosslaminated wall elements and the possibility this provided of obtaining sufficiently strong and stiff connections indicate the use of cross-laminated timber elements to have a strong stabilising potential in building construction involving timber.

\section{References}

Blass HJ, Fellmoser P (2004) Design of Solid Wood Panels with Cross Layers, Proceedings of the WCTE-meeting in Lahti, Finland

Dujic B, Pucelj J, Zarnic R (2004) Study of Innovative Wooden House Based on Racking Test of Solid Wall Panels. Proceedings of the COST-E29 meeting in Florence, Italy

Ellis BR, Bougard AJ (2001) Dynamic testing and stiffness evaluation of a six-storey timber framed building during construction. Eng Struct 23(10):1232-1242

Kasal B, Collins MS, Paevere P, Foliente GC (2004) Design models of light frame wood buildings under lateral loads. J Struct Eng ASCE 130(8):1263-1271

Källsner B, Lam F (1995) Diaphragms and shear walls. In: Holzbauwerke nach Eurocode 5 - STEP 3. Düsseldorf, Germany, p 15/1$15 / 19$

Moosbrugger T, Guggenberger W, Bogensperger T (2006) CrossLaminated Timber Segments Under Homogeneous Shear - With and Without Openings. Proceedings of the WCTE-meeting in Portland, USA 